\title{
A SURVEY OF ANTIFERTILITY AND ABORTIFACIENT AGENTS OF ZOOLOGICAL ORIGIN USED BY TRIBES OF RAJASTHAN
}

\author{
RASHID RASOOL RABBANI ISMAILI ${ }^{\mathrm{a} 1}$, SAMEERA GHAZAL ${ }^{\mathrm{b}}$ AND HASAN KHALID AZMI \\ ${ }^{\text {a } D e p a r t m e n t ~ o f ~ E c o l o g y ~ a n d ~ N a t u r e ~ C o n s e r v a t i o n, ~ B e i j i n g ~ F o r e s t r y ~ U n i v e r s i t y, ~ B e i j i n g, ~ C h i n a ~}$ \\ ${ }^{\mathrm{bc}}$ Department of Zoology, Shibli National College, Azamgarh, U.P., India
}

\begin{abstract}
Animals and plants have been employed as medicines in human civilization for millennia. Rajasthan is one of India's fauna and flora biodiversity hotspots. Rajasthan tribes account for roughly $13.48 \%$ of the population. Five districts viz. Banswara, Dungarpur, Jaipur, Swami, and Madhopur contribute 2/3 of Rajasthan state tribal population. Most tribal communities now prefer smaller families than in the past. Present study is intended to investigate the zootherapy used by tribes of Rajasthan for keeping space there in children and smaller families. This study was carried out from 2017 to 2018 . The medico-ethnozoological records acquired in this research are acquired through personal communication and interview of various tribes of Rajasthan. In order to cumulate the details of indigenous knowledge and experiences we also interviewed Probation Officers, Block Panchayat and Tribal Communities of Rajasthan in regard to their site, population and social stratum. These data were gathered for the local name of animals, parts of animals used and the mode of administration that was deemed valuable. A total of 17 animal species used in an abortifacient and antifertility treatment. It has been found out that animals used by these tribes consist of 9 mammals, 4 aves, 2 reptiles, 1 insect, and 1 bivalvia. The consequences of this research reveal a handful of peculiar and useful information about the therapeutic utilisation of different bodily organs of various animals for preventing pregnancy which are safe, effective, and convenient with no side effects. Need for scientific evaluation and scrutiny has been emphasized.
\end{abstract}

KEYWORDS: Tribes, Abortion, Spermicidal, Ethnozoology, Rajasthan, Conservation

From the long-standing experiences, it is mentioned that the ancient people capitalized on variety of opportunities from the natural world for their continuity in steep and remote forest area since time immemorial, and their intimate relation with the animal community is noteworthy (Azmi and Sinha, 2012). Animals' parts and products have been utilised to inventory healing ingredients in numerous culture.The medico-ethnozoological system has some very valuable remedies for different diseases, successfully treated by the healers of tribal descent. Their claims and beliefs are highly fascinating. The overall impression is that they have remedies for a wide variety of ailments. Nonetheless, the system may suffer from some drawbacks, pitfalls, and ostentatiousness. It is therefore imperative to know what is useful and what is useless. If these statements were submitted to extensive inquiries and critical review, it would be highly worthwhile in the zootherapeutic field. This treasure of information is a virgin field.

Now most tribal communities want smaller families than they did in the past. Over the last 30 years the size of average families in many tribal communities has fallen from roughly 6 children to about 3 due to some reasons such as poverty on a grand scale, women's ability to pursue their goals is severely limited by inequities between men and women, as well as early marriage. Throughout the tribal belts, the women want to delay or cease child bearing. To avoid pregnancy or inducing abortion they use contraceptives of animals origin which are safe, effective, convenient, spermicidal, and free from side- effects. Since the Mahawar and Jaroli (2006) are not hormonal, there is no possibilities of any after effects. It dissolves completely and routinely passes out. It does not intervene in the conjugal pleasure and couples derive full satisfaction as there is no artificial cover. Respectively, some significant initiatives have been taken in this area of study which promising valuable information of mammals, birds, reptiles, bivalvia, insects have been collected and reported by the authors. Hence the data accumulated are introduced in this paper.

\section{MATERIALS AND METHODS}

\section{Study Area}

The data used here for medico-ethnozoological study are purely based on the information accumulated

${ }^{1}$ Corresponding author 
through individuals and group interviews of the various tribes of Rajasthan. The segregation of the tribal people's distribution in different districts emanate from the tribal map of India (Gohain B.C., 1971). Rajasthan is India's largest state, with 344, 239 square kilometres (almost $11 \%$ of entire land area of the country) and located between $23^{\circ} 30^{\prime}$ and $30^{\circ} 12^{\prime}$ North latitude and $69^{\circ} 30^{\prime}$ and $78^{\circ} 17^{\prime}$ East longitude. Rajasthan has a vast range of climates and a diverse range of flora and fauna (Meena and Yadav, 2010). Rajasthan's climate is arid or semi-arid with four distinct seasons: summer (March-May) with temperature ranging from $23^{\circ} \mathrm{C}$ to $30^{\circ} \mathrm{C}$, winter (JanuaryFebruary) with temperature ranging from $2^{\circ} \mathrm{C}-25^{\circ} \mathrm{C}$, monsoon (July-September) with temperature ranging from $35^{\circ} \mathrm{C}-40^{\circ} \mathrm{C}$, post monsoon (October-December) with temperature ranging from $18^{\circ} \mathrm{C}-20^{\circ} \mathrm{C}$. East Rajasthan receives $64.9 \mathrm{~cm}$ yearly rainfall whereas west Rajasthan receives $32.7 \mathrm{~cm}$. The state's southern part get the most rainfall. Guzella and antelopes can be found in various parts of the state. The Rucervus duvauceli is a common sight in Jodhpur.

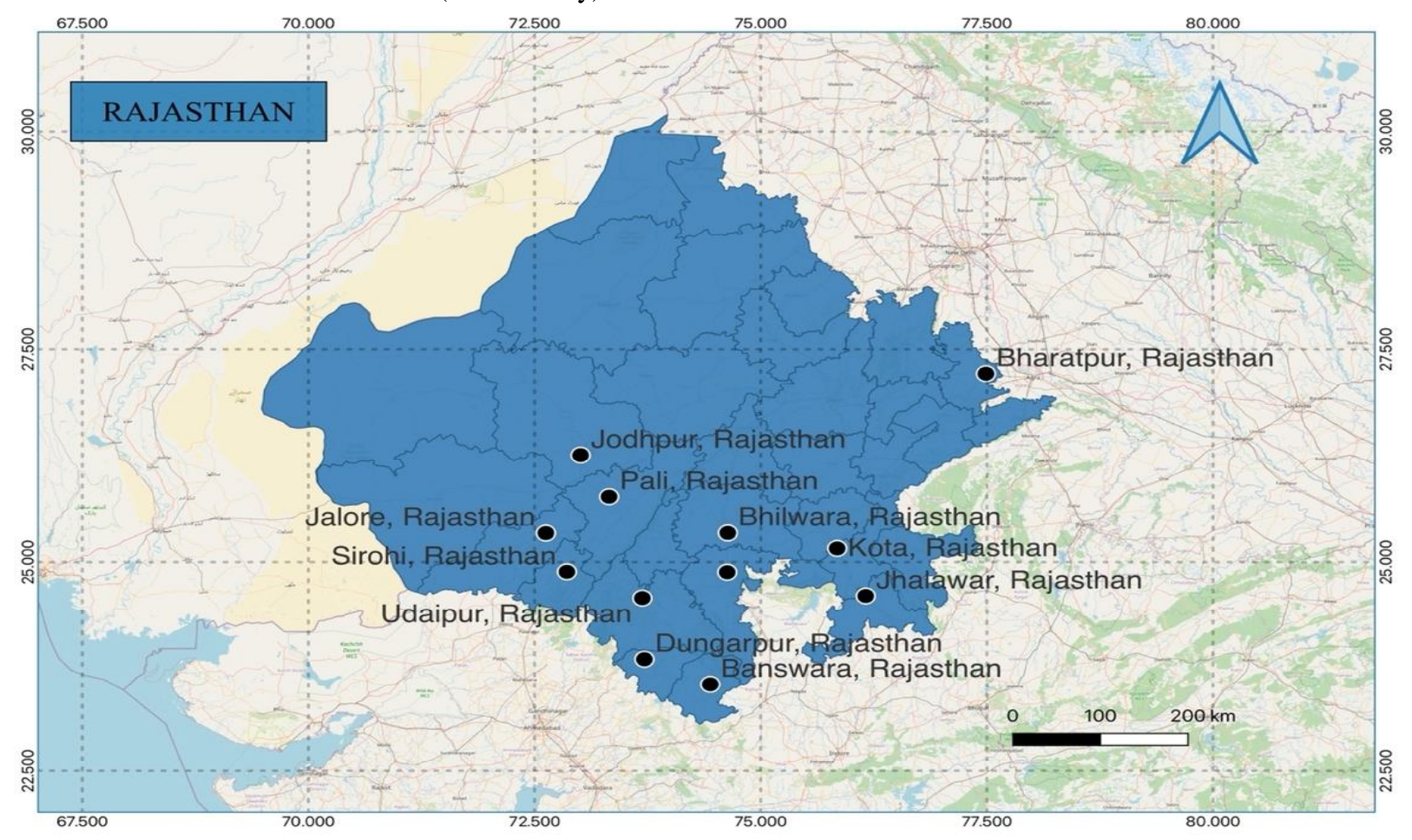

Figure 1: Map showing the locations of the ethnozoological research area

Tigers which have been designated as endangered can be seen at the Sariska and Ranthambore National parks (Mahawar and Jaroli, 2006). Panthera pardus is a threatened species, there are about 375 different bird species have been identified. This study was conducted in 12 districts (Banswara, Bharatpur, Bhilwara, Chittorgarh, Dungarpur, Jalore, Jhalawar, Jodhpur, Kota, Pali, Sirohi, and Udaipur), mostly in the southern part of Rajasthan were purposively chosen to inclusive of all such tribal communities in the study area along with the wide variety of flora and fauna., Figure 1.

\section{DATA COLLECTION}

A preliminary study was conducted in November 2017 to January 2018. Personal interviews and Focus Group discussions were performed among these informants to acquire information on the use of animals by seven tribes, mostly from Rajasthan. The interviews were conducted in accordance with conventional ethnobiological data collection methods. The respondents' age ranged between 27 to 50 years old. The duration of the interviews ranged from fifty minutes to one and a half hours. All the interviews were placed in the informants' native tongue. While obtaining inputs, we adhered to the International Society of Ethnobiology's ethical criteria as well as concurrence affirmation on ethnopharmacological field of investigation (Heinrich et al., 2018). The Grasia, Meena, and Bhil tribes were extremely cooperative and active participants in the session, and they were interviewed several times from different locations to a feasible extent in order to get error-free and detailed information about the contraceptive remedies derived from various animals. As a result, animal identification cards were utilised to aid memory recall and avoid the likelihood of discrepancies in species names when 
grouping species as one species allocated to a number of closely related species.

\section{RESULTS}

\section{Ethnozoological Exploration}

In the present study, we have analysed four animal species out of 17, which are presented in Table 1, as highly concerned species on the IUCN red list. Species as being of conservation concern, Elephas maximus wasdesignated as an endangered (EN) species, while Leptoptilo sdubius and Rucervus duvauceli were listed as vulnerable (UV) species, and Panthera pardus was listed as regionally extinct (RE). The investigator identified 17 animal species that were utilised to prevent or induce conception (Table 2). This group of 17 species includes both vertebrates $(60 \%)$ and invertebrates $(40 \%)$ species, with mammals accounting for the majority (53\%) followed by aves (23\%), reptiles (12\%), bivalvia and insects (6\% each). Figure 2

The study recorded, mammalian animals are the highest zootherapic creatures that can be used. However, according to other sources, mammals and reptiles are among the most commonly animals in folk medicine (Borah and Prasad, 2017). Mammals are also employed in traditional treatments in other parts of India, as it is mentioned in some reports (Borah and Prasad, 2017; Kim and Song, 2013). According to Alves and Rosa, the type of zootherapeutic resource used in a specific place is influenced by the fauna composition, accessibility, and availability (Kim and Song, 2013). Indigenous peoples' traditional medicinal knowledge has been crucial in identifying living organisms with therapeutic properties that can be usedto address human health concerns. Wild and domestic animals, as well as their products including bones, skin, blood, and internal organs are used to make therapeutic, protective, and preventive medicine.

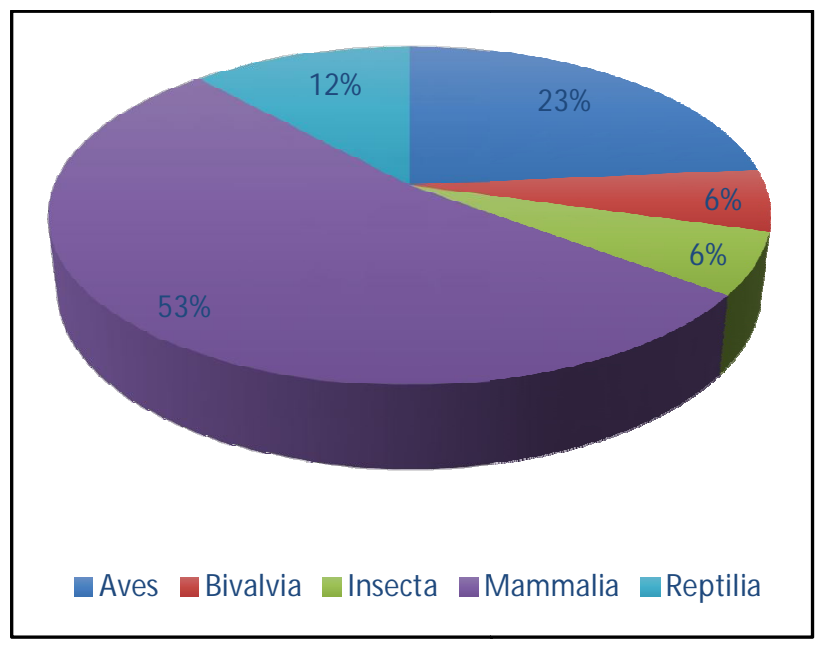

Figure 2: Segmental portrayal of sum-total of species and percentage of contribution amongst each class

Table 1: Endangered species of threatened animals concern conservation (according to IUCN report) that were used for Ethnomedicinal purposes by the tribal inhabitants of Rajasthan.

\begin{tabular}{|c|c|c|c|}
\hline Species & Common Name & IUCN Category & Population trend \\
\hline Canis lupus & Wolf & $\mathrm{LC}$ & Stable \\
\hline Columba livia & Pigeon & $\mathrm{LC}$ & Decreasing \\
\hline Elephas maximus & Elephant & $\mathrm{EN}$ & Decreasing \\
\hline E. africanus asinus $\delta \times$ E. ferus caballus? & Mule & $\mathrm{US}^{*}$ & $\mathrm{US}^{*}$ \\
\hline Falco perigrinus & Falcon & $\mathrm{LC}$ & Stable \\
\hline Felis lybica & Cat & $\mathrm{LC}$ & Unknown \\
\hline Gallus gallus & Hen & $\mathrm{LC}$ & Decreasing \\
\hline Homo sapiens & Human & $\mathrm{US}^{*}$ & $\mathrm{US}^{*}$ \\
\hline Leptoptilos dubius & Adjutant stork & VU & Decreasing \\
\hline Lepus nigricollis & Hare & $\mathrm{LC}$ & Unknown \\
\hline Naja naja & Cobra & $\mathrm{US}^{*}$ & $\mathrm{US}^{*}$ \\
\hline Panthera pardus & Leopard & $\mathrm{RE}$ & Unspecified \\
\hline Periplaneta americana & Cockroach & $\mathrm{US}^{*}$ & $\mathrm{US}^{*}$ \\
\hline Pinctada vulgaris & Pear oyster & $\mathrm{US}^{*}$ & $\mathrm{US}^{*}$ \\
\hline Rucervus duvaucelii & Antelope & $\overline{\mathrm{VU}}$ & Decreasing \\
\hline Uromastyx & Spiny tailed lizard & $\mathrm{LC}$ & $\mathrm{US}^{*}$ \\
\hline Viverricula indica & Civet cat & $\mathrm{US}^{*}$ & Stable \\
\hline
\end{tabular}

* US: Species not specified in IUCN red data list (Version-3; 2017). 


\section{ANIMAL CONSTITUENTS AS REMEDY}

The medication for abortifacient and contraceptive was processed based on the findings of the medico-ethnozoological study. Excreta was found to be the most commonly used method to prevent pregnancy and cause abortion (26.3\%), followed by rennet and bile (10.5\%), and brain, civet, ear secretion, egg, hair, scale, urine, uterine secretion, and whole body/extract (5.26 percent each). Figure 3 Excreta of animal species used as most common remedy for conception prevention as excreta of animal species like Leptoptilos dubius, Elephas maximus, Falco perigrinus, Gallus gallus, and Columba livia used as a pessary, whereas inhaling the vapours of dried, burnt excreta causes abortion. Faecal medications were commonly used to treat disorders of the gastrointestinal tract, neurological system, skin, and gynaecology.

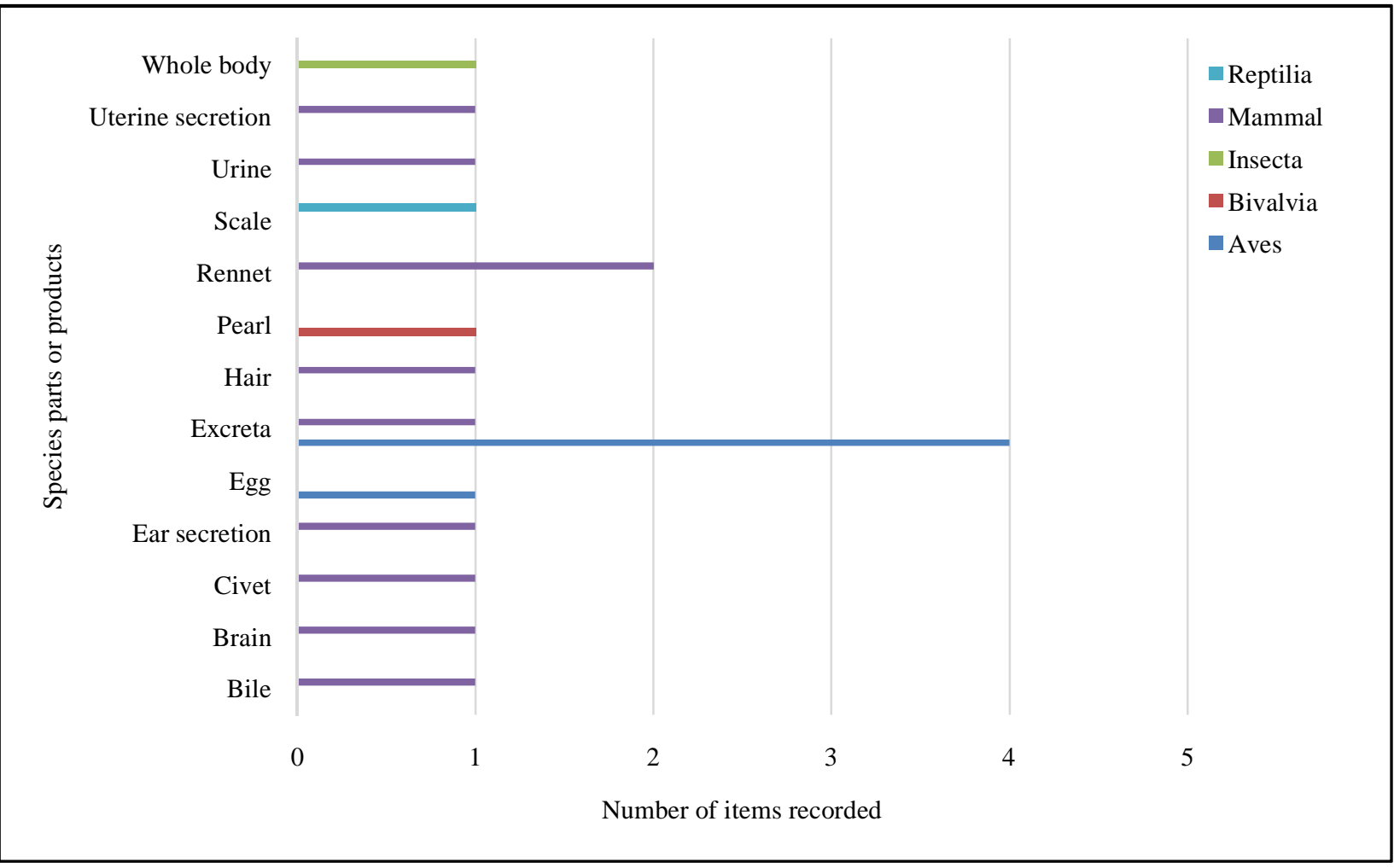

Figure 3: Bar graph showing the species parts and products used by tribes of Rajasthan as antifertility and abortifacient agents.

\section{Relative Frequency of Citation (RFC)}

The common affiliation of each species is designated by the Relative Frequency of Citation Index. The RFC standard was calculated using the formula $\mathrm{RFC}=\mathrm{FC} / \mathrm{N}$, where $\mathrm{FC}$ denotes the number of respondents who notified the utilisation of species and $\mathrm{N}$ denotes the total number of respondents who participated in the survey.The RFC index varied from 0 to 1 , with a value of 0 representing the profitability of the species. If the RFC value is 1 indicates all survey participants refer to the animals as appropriate. The relative frequency of citation was produced to establish the common connection of each species. The most cited animal species were Gallus gallus $(\mathrm{RFC}=0.66)$, Periplaneta americana $(\mathrm{RFC}=0.56)$, E. africanus asinus $\times$ E. feruscabillus $(\mathrm{RFC}=0.53)$, Elephas maximum $(\mathrm{RFC}=0.44)$, Rucervus duvaucelii ( $\mathrm{RFC}=0.43)$, Canis lupus $(\mathrm{RFC}=0.39)$, Lepoptilo sdubius $(\mathrm{RFC}=0.35), \quad$ Falco perigrinus $(\mathrm{RF}=0.34)$, Najanaja (0.32), Viverricula indica (0.29), Panthera pardus (0.27), Homo sapiens (0.23) Uromastyx (0.22) while, Columba livia, Felis lybica, Lepus nigricollis, and Pinctada vulgaris had the lowest RFC values $(0.08,0.06,0.04$, and 0.03, respectively). Gallus gallus received the highest RFC index score, demonstrating the use of these species in the examined site of Rajasthan, India, as informed by informants. Species with least Citation Relative Frequency values, such as Columba livia $(\mathrm{RFC}=0.08)$, Felis lybica $(0.06)$, Lepus nigricollis (0.04), and Pinctada indica (0.03), do not beside the point that they are not beneficial locally; rather, it is possible that the majority of tribes are not aware of their therapeutic properties. 
Table 2: The list of the Ethnomedicinal animals used by the aboriginals of Rajasthani tribes in contraception and abortion.

\begin{tabular}{|c|c|c|c|c|c|}
\hline $\begin{array}{l}\text { Name of } \\
\text { Animals }\end{array}$ & $\begin{array}{l}\text { Scientific } \\
\text { Name }\end{array}$ & $\begin{array}{l}\operatorname{Part}(\mathbf{s}) \\
\text { used }\end{array}$ & Mode of administration & $\begin{array}{l}\text { Name of } \\
\text { Tribe(s) }\end{array}$ & $\begin{array}{c}\text { Name of } \\
\text { District (s) }\end{array}$ \\
\hline $\begin{array}{l}\text { Adjutant } \\
\text { stork }\end{array}$ & $\begin{array}{l}\text { Lepoptilos } \\
\text { dubius }\end{array}$ & Excreta & $\begin{array}{l}\text { Used as intravaginal pessary - prevent } \\
\text { pregnancy. } \\
\text { Dried, burnt and the resultant fume are inhaled } \\
\text { for 2-3 minutes, twice a day for 3-4 days, after } \\
\text { menstruation - induces abortion. }\end{array}$ & $\begin{array}{l}\text { Bhil, } \\
\text { Domar, } \\
\text { Gameti, } \\
\text { Mina }\end{array}$ & $\begin{array}{l}\text { Bundi, Pali, } \\
\text { Sirohi, } \\
\text { Bharatpur }\end{array}$ \\
\hline Antelope & $\begin{array}{l}\text { Rucervus } \\
\text { duvaucelii }\end{array}$ & Rennet & $\begin{array}{l}\text { Dried, powdered and taken with honey 2-3 time } \\
\text { a day, for a week, 3-4 days after menstruation - } \\
\text { induces abortion } \\
\text { Used as intravaginal pessary. } \\
\text { Burnt and emerging fume are inhaled deeply, } \\
\text { twice a day for one week, 3-4 days after } \\
\text { menstruation. }\end{array}$ & $\begin{array}{l}\text { Domar, } \\
\text { Bhil, } \\
\text { Garasia, } \\
\text { Bhil }\end{array}$ & $\begin{array}{l}\text { Kota, } \\
\text { Jhalaawar, } \\
\text { Udaipur, } \\
\text { Bhilwara }\end{array}$ \\
\hline Cat & Felis lybica & Brain & $\begin{array}{l}\text { Burnt in a closed vessel, the resultant fumes } \\
\text { inhaled which causes abortion, once a day for } \\
\text { one week. }\end{array}$ & Mina & $\begin{array}{l}\text { Bundi, } \\
\text { Udaipur, Pali }\end{array}$ \\
\hline Civet Cat & $\begin{array}{l}\text { Viverricula } \\
\text { indica }\end{array}$ & Civet & $\begin{array}{l}\text { Locally applied on male organ before } \\
\text { intercourse. It is spermicidal in nature. }\end{array}$ & $\begin{array}{l}\text { Korwa, } \\
\text { Bhil }\end{array}$ & $\begin{array}{l}\text { Pali, Kota, } \\
\text { Jodhpur }\end{array}$ \\
\hline Cobra & Naja naja & Scale & $\begin{array}{l}\text { Incinerated, mixed with honey, and given it to } \\
\text { the ladies in the first term of the pregnancy, } \\
\text { twice a day for one week. It induced abortion. }\end{array}$ & $\begin{array}{l}\text { Mina, } \\
\text { Saharia, } \\
\text { Bhil, } \\
\text { Korwa }\end{array}$ & $\begin{array}{l}\text { Chittoorgarh, } \\
\text { Udaipur, } \\
\text { Sirohi, } \\
\text { Banswara }\end{array}$ \\
\hline Elephant & $\begin{array}{l}\text { Elephas } \\
\text { maximus }\end{array}$ & Excreta & $\begin{array}{l}\text { Extract applied intravaginal cause antifertility. } \\
\text { The extract taken with milk once a week - } \\
\text { prevents pregnancy. } \\
\text { Burnt, emerging fumes inhaled deeply - induced } \\
\text { abortion. }\end{array}$ & $\begin{array}{l}\text { Bans, } \\
\text { Korwa, } \\
\text { Bhil }\end{array}$ & $\begin{array}{l}\text { Banswara, } \\
\text { Dungarpur, } \\
\text { Jalore, } \\
\text { Bhilwara }\end{array}$ \\
\hline Cockroach & $\begin{array}{l}\text { Periplaneta } \\
\text { americana }\end{array}$ & $\begin{array}{l}\text { Whole } \\
\text { body } \\
\text { (Extract) }\end{array}$ & $\begin{array}{l}\text { Burnt, ash mixed with honey and orally taken for } \\
3 \text { days after menstruation - prevents pregnancy. } \\
\text { Applied as pessary } 4-5 \text { minutes before } \\
\text { intercourse. }\end{array}$ & $\begin{array}{l}\text { Gameti, } \\
\text { Domar, } \\
\text { Bhil, } \\
\text { Mina }\end{array}$ & $\begin{array}{l}\text { Jhalawara, } \\
\text { Kota, Pali. } \\
\text { Jalbre. }\end{array}$ \\
\hline Falcon & $\begin{array}{c}\text { Falco } \\
\text { perigrinus }\end{array}$ & Excreta & $\begin{array}{l}\text { Used as pessary - causes antifertility. } \\
\text { Burnt fumes inhaled deeply 3-4 times a day, for } \\
\text { 4-5 days - prevents pregnancy. }\end{array}$ & $\begin{array}{l}\text { Mina, } \\
\text { Korwa, } \\
\text { Saharia }\end{array}$ & $\begin{array}{l}\text { Pali, Kota, } \\
\text { Bharatpur }\end{array}$ \\
\hline Human & $\begin{array}{l}\text { Homo } \\
\text { sapiens }\end{array}$ & Hair & $\begin{array}{l}\text { Burnt in a closed vessel emerging fume inhaled } \\
\text { deeply 2-3 times a day for about } 1 \text { week. }\end{array}$ & $\begin{array}{l}\text { Bhil, } \\
\text { Korwa }\end{array}$ & $\begin{array}{l}\text { Kota, } \\
\text { Jodhpur }\end{array}$ \\
\hline
\end{tabular}


Table 3: The list of the Ethnomedicinal animals used by the aboriginals of Rajasthani tribes in contraception and abortion.

\begin{tabular}{|c|c|c|c|c|c|}
\hline $\begin{array}{l}\text { Name of } \\
\text { Animals }\end{array}$ & $\begin{array}{l}\text { Scientific } \\
\text { Name }\end{array}$ & $\begin{array}{c}\text { Part(s) } \\
\text { used }\end{array}$ & Mode of administration & $\begin{array}{l}\text { Name of } \\
\text { Tribe(s) }\end{array}$ & $\begin{array}{c}\text { Name of } \\
\text { District (s) }\end{array}$ \\
\hline Hen & $\begin{array}{l}\text { Gallus } \\
\text { gallus }\end{array}$ & $\begin{array}{l}\text { Egg\& } \\
\text { Excreta }\end{array}$ & $\begin{array}{l}\text { 2-3 raw eggs, mixed with a glass of country } \\
\text { liquor given during 3-4 months of pregnancy } \\
\text { for abortion. } \\
\text { Little excreta dissolved in curd and consumed } \\
\text { by the ladies for } 4-5 \text { days twice a day, } 3-4 \text { days } \\
\text { after menstruation - induced abortion. } \\
\text { A globule of excreta mixed with the little } \\
\text { jaggery and consumed by the ladies for } 1-2 \\
\text { days - induced abortion. } \\
\text { 2-3 raw eggs mixed in a glass of cow's urine } \\
\text { and given in pregnancy between 3rd and } 4 \text { th } \\
\text { month - induced abortion. } \\
\text { A hole is made in the shell of egg, some } \\
\text { quantity of opium and half teaspoon full } \\
\text { powder of dried powder of paddy roots is } \\
\text { pushed into the yolk then the cell is completely } \\
\text { covered with cow dung and roasted on fire and } \\
\text { consumed by the ladies in first term of } \\
\text { pregnancy, once daily for about one week - } \\
\text { induced abortion. }\end{array}$ & $\begin{array}{l}\text { Bhil, Domra, } \\
\text { Korwa } \\
\text { Mina,Saharia, }\end{array}$ & $\begin{array}{l}\text { Chittoorgarh, } \\
\text { Sirohi, } \\
\text { Jodhpur, } \\
\text { Bharatpur } \\
\text { Kota, } \\
\text { Jhalaawar, } \\
\text { Jallor }\end{array}$ \\
\hline Hare & $\begin{array}{c}\text { Lepus } \\
\text { nigricollis }\end{array}$ & Rennet & $\begin{array}{l}\text { Taken orally } 3 \text { days after menstruation - } \\
\text { prevents pregnancy. }\end{array}$ & Bhil & Bharatpur \\
\hline Leopard & $\begin{array}{l}\text { Panthera } \\
\text { pardus }\end{array}$ & $\begin{array}{l}\text { Uterine } \\
\text { secretion }\end{array}$ & $\begin{array}{l}\text { Orally taken with milk once twice daily for } 1 \\
\text { week, } 3 \text { - } 4 \text { days after menstruation. } \\
\text { Used as pessary } 4-5 \text { minutes before } \\
\text { intercourse. } \\
\text { Locally applied on male organ before } \\
\text { intercourse. }\end{array}$ & $\begin{array}{l}\text { Mina, Korwa } \\
\quad \text { Bhil }\end{array}$ & $\begin{array}{l}\text { Kota, } \\
\text { Jodhpur, } \\
\text { Bharatpur }\end{array}$ \\
\hline Pigeon & $\begin{array}{l}\text { Columba } \\
\text { livia }\end{array}$ & Excreta & Taken orally - causes sterility in women. & $\begin{array}{l}\text { Saharia, } \\
\text { Mina, Korwa }\end{array}$ & $\begin{array}{c}\text { Kota, } \\
\text { Bharatpur, } \\
\text { Udaipur }\end{array}$ \\
\hline $\begin{array}{l}\text { Pearl } \\
\text { Oyster }\end{array}$ & $\begin{array}{c}\text { Pinctada } \\
\text { vulgaris }\end{array}$ & Pearl & Used as pessary - prevents pregnancy. & Mina & Jodhpur \\
\hline Mule & $\begin{array}{c}\text { E. } \\
\text { africanus } \\
\text { asinus } \hat{\jmath} \times \\
\text { E. ferus } \\
\text { caballus } 9\end{array}$ & $\begin{array}{l}\text { Ear } \\
\text { section } \\
\text { Urine } \\
\end{array}$ & $\begin{array}{l}\text { Taken orally twice daily causes even for } 3 \\
\text { months of pregnancy. } \\
\text { Used as pessary - prevent pregnancy. } \\
\text { If taken in large doses - cause abortion. } \\
\text { Used as pessary prevents pregnancy. }\end{array}$ & $\begin{array}{l}\text { Bhil, } \\
\text { Mina, } \\
\text { Mina }\end{array}$ & $\begin{array}{l}\text { Kota, } \\
\text { Jodhpur, } \\
\text { Kota }\end{array}$ \\
\hline $\begin{array}{l}\text { Spiny } \\
\text { tailed } \\
\text { lizard }\end{array}$ & $\begin{array}{l}\text { Uromastyx } \\
\text { hardwickii }\end{array}$ & Bile & $\begin{array}{l}\text { Applied intravaginal or used as pessary before } \\
\text { intercourse - act as spermicidal }\end{array}$ & Mina, Saharia & $\begin{array}{l}\text { Bharatpur, } \\
\text { Udaipur }\end{array}$ \\
\hline Wolf & $\begin{array}{l}\text { Canis } \\
\text { lupus }\end{array}$ & Bile & $\begin{array}{l}\text { Used as pessary - induces abortion. } \\
\text { Locally applied on male organs before } \\
\text { intercourse - prevent pregnancy. }\end{array}$ & $\begin{array}{l}\text { Korwa, } \\
\text { Domar, } \\
\text { Mina, Bhil }\end{array}$ & $\begin{array}{c}\text { Pal, } \\
\text { Sirohi, } \\
\text { Bhilwara, } \\
\text { Jhaalwara }\end{array}$ \\
\hline
\end{tabular}




\section{DISCUSSION}

The medico-ethnozoological data presented in this paper reveals peculiar and useful information about the curative application of different body parts/organs of distinct animals by Rajasthan's tribes. Only few sanctions found place in earlier text while greater number of these advocations are unconventional. Perusal of literatures did not indicate antifertility and abortifacient activity of some parts namely: excreta, bile, hair, urine, uterine secretion, brain, and scale are placed under cover this report. None the less, the therapeutic application of some collated in prior research. The use of pessaries from the excreta of adjutant stork and elephant, civet of civet cat, urine of mule and leopard, ear section of mule, bile of uromastyx and wolf are recommended for preventing the pregnancy (Kim and Song, 2013). These pessaries are safe, effective, convenient and spermicidal. These pessaries are not harmful and have no side effects and do not cause any sort of bleeding or pain associated with its uses within the body. It dissolves completely and routinely passes out (Vohra and Khan 1978). Similarly the rennet, civet, excreta, eggs are also orally recommended for antifertility and abortion. Bile of wolf and uromastyx are considered as spermicidal and used intravaginal or applied on phallus and fumes of hairs, excreta also recommended for abortion (Nadkarni and Nadkarni, 1976). This report may excite biomedical scientists a curiosity that may ultimately lead to momentous undertakings to explore the potentialities, effectiveness and proper utilization of such drugs in our current struggle against increasing rate of population.

\section{CONCLUSION}

This is the first study to document tribal people's traditional Zootherapeutic understanding of contraception and inducing abortion. In this study, it was discovered that the zoological method of contraception has no side effects, no bleeding, and no pain, however the modern method of abortion and contraception has certain adverse effects, breakthrough bleeding, and pain linked with its use within the body, according to resources. This report may pique the interest of biomedical scientists, leading to a significant initiative to investigate the potential, effectiveness, and suitable application of such pharmaceuticals in our current battle against population growth. This research will also serve as a foundation for future functional bioactivity screening of indigenous species and the conservation of vulnerable animals with medicinal potential.

\section{ACKNOWLEDGMENTS}

Sincere thanks are due to Dr. P.K. Maiti, Retd. Scientist-'D', Zoological Survey of India, for precious suggestions during the present work.

\section{REFERENCES}

Albuquerque et al. (2019). Methods and Techniques in Ethnobiology and Ethnoecology. Humana Press, New Jersey, United States.

Azmi H.K. and Sinha G., 2012. The role of invertibrates as traditional drugs prevalent among the tribals of Orissa-part-1. Indian J.Sci.Res., 3(1):137-140.

Borah M.P. and Prasad S.B., 2017. Ethnozoological study of animals based medicine used by traditional healers and indigenous inhabitants in the adjoining areas of Gibbon Wildlife Sanctuary, Assam, India. J. Ethnobiol. Ethnomedicine, 13:39.

Gohain B.C., 1971. Tribal map of India (based on 1961 census). Anthropological Survey of India, Calcutta.

Heinrich M., Lardos A., Leonti M., Caroline W. and Merlin W., 2018. Best practice in research: Consensus Statement on Ethnopharmacological Field Studies - ConSEFS. J. Ethnopharmacol, 211: 329-339.

Kim H. and Song M.J., 2013. Ethnozoological study of medicinal animals on Jeju Island, Korea. J. Ethnopharmacol, 146: 75-82.

Mahawar M.M. and Jaroli D.P., 2006. Animals and their products utilized as medicines by the inhabitants surrounding the Ranthambhore National Park, India. J. Ethnobiol. Ethnomedicine, 2: 46.

Meena K. and Yadav B., 2010. Some ethnomedicinal plants of Southern Rajasthan. Indian J. Tradit. Knowl., 9: 169-172.

Nadkarni K.M. and Nadkarni A.K., 1976. Dr. K.M. Nadkarni's Indian materia medica: with Ayurvedic, Unani-Tibbi, Siddha, allopathic, homeopathic, naturopathic \& home remedies, appendices \& indexes. Popular Prakashan Private Ltd, Bombay, India.

Vohra S.B. and Khan M.S.Y., 1978. Animal origin drugs used in Unani medicine. Indian J. Pharmacol., 10. 